\title{
Determinants of Web-technology Investment in Malaysian Logistics Industry: An Application of Technological, Organizational and Environmental (TOE) Model
}

\author{
Nuraishah Raimee \\ Faculty of Accountancy and Management \\ Universiti Tunku Abdul Rahman \\ 43000 Sungai Long, Selangor, Malaysia \\ E-mail: nuraishah@utar.edu.my \\ Intan Salwani Mohamed (Corresponding author) \\ Accounting Research Institute \& Faculty of Accountancy \\ Universiti Teknologi MARA \\ 40450 Shah Alam, Selangor, Malaysia \\ E-mail: intan838@uitm.edu.my
}

\begin{abstract}
Nabilah Rozzani
Faculty of Business Management and Professional Studies

Management and Science University

40100 Shah Alam, Selangor, Malaysia

E-mail: nabilah_rozzani@msu.edu.my
\end{abstract}

Received: September 28, 2020 Accepted: February 24, $2021 \quad$ Published: March 1, 2021

doi:10.5296/bms.v12i1.18364ＵRL: https://doi.org/10.5296/bms. v12i1.18364 


\section{Abstract}

This study is intended to seek empirical evidence on factors determining web technology investment in the Malaysian logistics industry. Technological, Organizational and Environmental (TOE) Model is used as a basis to examine the determinants of web technology investments under three characteristics; technological characteristics (technology competence and web functionalities); organizational characteristics (firm size, firm scope, and managerial beliefs); and environmental characteristics (regulatory support and pressure intensity). Questionnaire surveys were sent to 169 companies listed in the directory of the Malaysian logistics industry. It was found that five factors (web functionalities (WF), firm size (FZ), managerial beliefs (MB), regulatory support (RS), and pressure intensity (PI)) significantly influenced web technology investment. This study provides a greater understanding on the perceptions of the Malaysian logistics industry towards web technology investment.

Keywords: Web-technology Investment, TOE Model, Logistics Industry, Malaysia

\section{Introduction}

\subsection{Preamble}

The availability of web sites for twenty-four hours a day provides us an indication that online platforms are accessible at any time to our convenience. Efficiencies are created on online commercials in efforts to perform strategic marketing via Web results, for example, "10 times as many units [sold] with $1 / 10$ the advertising budget" as claimed by Porter (1995). According to Lin and Ho (2008), also Nguyen (2020), the definition of logistics services has evolved from being a tactical requirement into a strategic activity that links customers and suppliers by managing the flows of goods, services, and information from the point of origin to the point of consumption. Currently, the logistics industry has realized its potential with the advancement of information technology (IT). According to Hasan and Abuelrub (2006), if corporate organizations intend to change in correspondence to the Internet's outburst, they should seize all available opportunities related to technology, even if it means that the companies have to face more risks than ever before. According to Thurasamy, Mohamad, Omar, and Marimuthu (2009), the adoption of technology in Malaysia has been relatively low compared to other countries. IT penetration rate is slow, especially for Malaysian local enterprises. Thurasamy et al. (2009), also Ahmed, Qin, and Martinez (2019), argued that small businesses are more likely to move at a slower pace than larger businesses when it comes to web technology adoption. Due to these reasons, this study aims to look at factors determining web technology investment in the Malaysian logistics industry using the technology-organization-environment (TOE) framework founded by Tornatzky and Fleischer (1990). This study attempts to determine the extent to which technological characteristics such as technology competence and web functionalities would influence web technology investment in Malaysia's logistics industry; the extent to which organizational characteristics (firm size, firm scope, and managerial beliefs) would influence web technology investment in 
Malaysia's logistics industry; also the extent to which environmental characteristics (regulatory support and pressure intensity) would influence web technology investment in Malaysia's logistics industry.

\subsection{Logistics and IT}

Since its inception, the Internet has been loosely seen as a network for an abundance of computer networks. However, this advancement appears to be prominent with the concept of being a novel, efficient tool employed to access, organize, and share a wide range of information (Ainscough \& Luckett, 1996). The Malaysian logistics industry includes mainly specialized service providers such as transport operators, freight forwarders, and warehousing services. The global logistics industry has realized IT's potential if it is man-handled skillfully (MITI, 2010). The IT industry has given way for more partnerships to be established in chain supply and e-commerce. With these partnerships, IT broadens business opportunities and potential with the aid of adequate web technology investment. The rapid pace made by the World Wide Web has propelled many firms to re-evaluate and even re-work their methods of sharing and delivering important business data and information (Kalakota \& Whinston, 1996). E-logistics is one component of diverse web-based technologies available to support the material acquisition, warehousing, and transportation processes (Georgise, Heramo \& Bekele, 2020). This technological component enables the distribution process to be enhanced with couple routing optimization, together with the wonderfully useful inventory tracking information (Turban \& King, 2006).

\subsection{Theories on IT Adoption}

As IT becomes highly diversified across various disciplines, researchers have developed several theories related to IT adoption. By individual characteristics, the past researcher had argued that technology adoption could be explained by various theories and models such as the theory of reasoned action (TRA) (Fishbein \& Ajzen, 1977), the theory of planned behavior (TPB) (Ajzen, 1985), and the diffusion of innovations (DOI) theory (Rogers, 1995), which were developed to explain user beliefs, attitudes, intentions, and actual system use. On the other hand, the widely known technology acceptance model (TAM) (Davis, 1989) and unified theory of acceptance and use of technology (UTAUT) (Venkatesh et al., 2003) is used in many studies to explain the adoption decisions of IT. Although various models were introduced to address the acceptance or rejection of information systems, there is still a lack of existing studies regarding the technology-organization-environment (TOE) framework. According to Salahshour Rad, Nilashi, and Mohamed Dahlan (2018), only 22 research papers out of 330 papers investigating IT adoption between 2006 to 2015 had utilized TOE, hence gives a gap of knowledge in investigating the impact of IT adoption in organizations. This is because the TOE framework explicitly identifies aspects of a business context that influence the process by which it adopts and implements a technological innovation (Oliviera \& Martins, 2011). Hence, the current study decided to assess factors determining web technology investment in the Malaysian logistics industry using the TOE framework. 


\subsection{Technology, Organizational and Environment Model (TOE)}

Technology, Organizational and Environment Model (TOE) is a framework developed by Tornatzky and Fleischer (1990). The TOE model is widely adapted when researchers seek to examine the determinants of technology usage, application, and routinization (Zhu et al., 2006; Martins et al., 2019). As firms in the present time become more dependent on IT to better promote their services and improve their overall performance, they become forced to transform their traditional business system, which is heavily dependent on physical processes, to a process that relies more on digital assets and information flow (Zhu and Kraemer, 2005). The TOE model is often used to elaborate organizational components that are important to be evaluated before any decisions are made on the firm's IT adoption. According to Bellaaj et al. (2008) and Mohamed et al. (2009), this model asserts three principal characteristics: technological, organizational, and environmental characteristics. These characteristics were argued to impact an overall process by which an organization adopts and accepts new technology. Technological characteristics consist of technology competence; organizational characteristics consist of firm size and managerial beliefs, while environmental characteristics consist of pressure intensity (Mohamed et al., 2009).

\subsection{Hypothesis Development}

Sekaran (2003) mentioned that a theoretical framework is a conceptual model on how one theorizes or makes logical sense of the relationships among several factors under study. The primary variable of this study is web technology investment. There are seven independent variables, which are:

\section{a) Technology competence}

According to Mohamed et al. (2009), technological competence consists of IT infrastructure, human resources, knowledge sharing, and knowledge management. It was argued by Burke and Witt (2002) that to gain a competitive advantage, organizations need to dedicate substantial investment to IT. As such, retaining qualified IT professionals of high caliber is critical.

\section{b) Web functionalities}

Based on Chatterjee et al. (2002), web technologies suggest various functionalities, from a static presentation of content to active capture of transactions. The back-end integration allows for technology incorporated within the organization, making information sharing much easier with suppliers and business partners (Zhu \& Kraemer, 2002).

\section{c) Firm size}

According to Mohamed et al. (2009), firm size is often used in the TOE Model as it is a good predictor of IT adoption within an organization. It was theorized that larger organizations would have more financial and technology resources to invest in new technologies. Hence they can absorb any risks associated with these technologies (Tan, Chong \& Lin, 2010). 
Larger businesses would interact more frequently with the external environment than smaller businesses as they would have more exposure to innovations (Swanson, 1994; Cremer \& Ramasamy, 2009). However, Schiederjan et al. (2004) believed that size must be thoroughly researched in conjunction with the activity sector. Zhu and Kraemer (2005) found that firm size has a significant negative path leading to a dependent construct of E-business usage.

\section{d) Firm scope}

The firm scope is another commonly studied organizational factor in the Information Systems literature (Dewan, Michael \& Min,1998). According to Terence (2007), IT provides global competition for firms to reduce geographical boundaries. Hitt (1999) found that the greater the firm's scope, the greater its demand for web technology investment. Besides that, firms involved in a greater variety of activities are likely to find a given technology applicable to their operations range (Tornatzky \& Fleischer 1990).

e) Managerial beliefs

Numerous researchers have identified managerial beliefs as a key factor of diffusion for IT implementation (Al-Qirim, 2007). Managerial belief, regardless of it being positive or negative, is an important antecedent that needs to be instilled before any strategic choices can be made (Child, 1997; Carmeli, Dothan \& Boojihawon, 2019). Several researchers have found that managerial interpretation and discretion of organizational and environmental forces play a critical role in explaining strategic choices (Coltman, Devinney \& Midgley, 2003). An empirical study by Igbaria, Zinatelli, and Cayave (1998) found that the key role in driving technology innovation is very much placed on the responsibility that the top management should shoulder. This argument was supported by Gould (2001), who recognized that senior management support is one of the three main factors which is necessary for a successful web technology investment.

\section{f) Pressure intensity}

The marketplace is increasingly competitive for many industries, where many major firms have been willing to explore the adoption of innovations to gain a competitive advantage (Tarofder, Marthandan \& Haque, 2010). Reich and Benbasat (1990), also To and Ngai (2006), argued that in an environment where a firm perceives a high level of competitive intensity and rivalry, the firm would be more likely to allocate funds for the adoption of innovations. This decision results in a greater level of overall innovation within the firm. One reason for organizations to make web technology investment is due to the firm's desire and need to stay competitive and innovative as a necessity for their survival (MacKay, Parent, and Gemino, 2004).

\section{g) Regulatory support}

A study on Internet use found that government endorsement was one of the dominant factors for internet growth in Singapore (Goh, 1996). Successful Internet businesses saw a significant role for the government, particularly in providing information and independent advice; 
providing support and assistance in developing geographically broader customer base; providing professional advice on international trade and promotion overseas; as well as becoming a role model for the use of IT (Castleman, Swatman \& Swatman, 2000; Zhu \& Kreamer, 2005; Mohamed et al., 2009). This result affirmed the government's role in carving a raised IT adoption status in Singapore (Toh \& Low, 1993).

h) Web technology investment

According to Benbunan-Fich and Fich (2005), web technology investment is defined as the cost incurred with any acquisition of computer hardware, network facilities, pre-developed software, or any in-house systems development project, which is expected to add to or enhance an organization's information system capabilities and produce benefits beyond the short term.

Based on the underlying TOE Theory and discussion from previous literature, nine hypotheses were developed for this study in accordance with various factors that act as drivers towards web technology investment. The hypotheses tested in this study are presented as follows (see Figure 3.1).

H1: Technology competence significantly influences web technology investment.

$\mathrm{H} 2$ : Web functionalities significantly influence web technology investment.

H3: Firm size significantly influences web technology investment.

H4: Firm scope significantly influences web technology investment.

H5: Managerial beliefs significantly influence web technology investment.

H6: Regulatory support significantly influences web technology investment.

H7: Pressure intensity significantly influences web technology investment. 


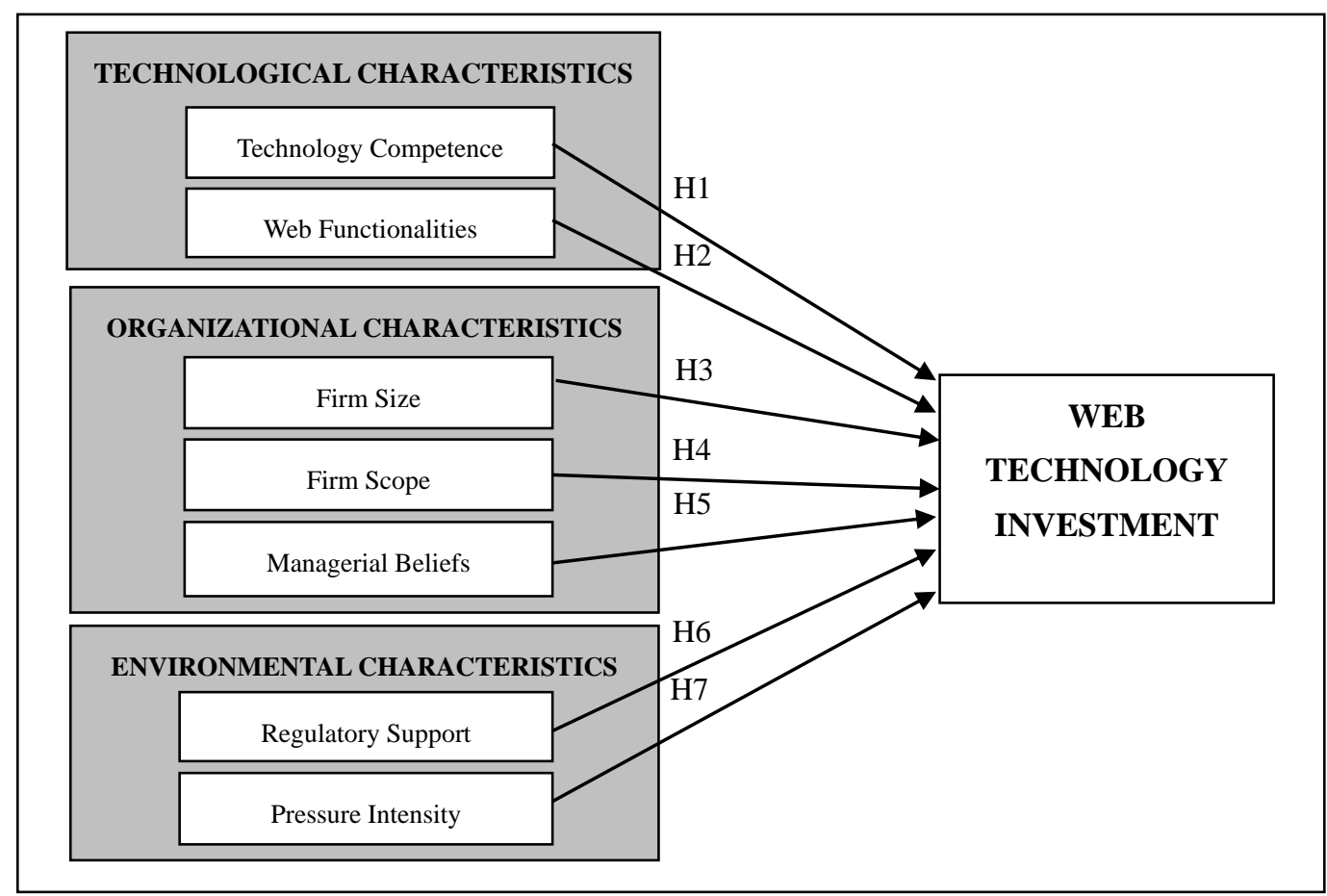

Figure 3.1 Theoretical framework for this study

\section{Research Methodology}

\subsection{Sampling Procedure}

It was estimated that about 296 companies are operating within the Malaysian logistics industry. According to the Malaysian Logistics Directory, 108 companies are involved in transportation services, while 188 companies are involved in supporting industries. Most of these companies have their official websites. Concerning this information, the sample for this study was selected using random sampling. The sample size was determined according to a table provided by Sekaran (2003). Since this study's population is 296, close to 300, a sample size of 169 companies was required.

\subsection{Data Collection and Analysis Procedures}

Data collection for this study had relied mainly on the distributed questionnaire. There were several blank responses found from the returned questionnaires. However, this issue was resolved using a rule of thumb by Sekaran (2003), which stated that the data should still be included for analysis as long as the questionnaires' unanswered part does not exceed $25 \%$. In this study, the questionnaire distribution response rate was 38.64 percent; hence, no sample bias, as suggested by Hussey and Hussey (1997). Data were analyzed using the Statistical Package for Social Science (SPSS) software on version 17.0 to execute statistical procedures for extracting useful information from the raw data to make informed decisions.

\section{Findings}

Data were analyzed using frequency distribution of demographic variables and reliability tests. 


\subsection{Frequency Distribution of Demographic Variables}

Respondents who answered this study's questionnaires varied in their demographics information such as industry sub-sector, working position, and the starting year for which the organizations had developed their websites. Using the frequency distribution of demographic variables, findings are reflected in Table 4.1.

Table 4.1 Sample Characteristics $(\mathrm{N}=65)$

\begin{tabular}{|c|c|c|c|}
\hline & Frequency & Percent & Cumulative Percent \\
\hline \multicolumn{4}{|l|}{ Industry Sub Sector } \\
\hline Airfreight & 4 & 6.2 & 6.2 \\
\hline Sea freight & 17 & 26.2 & 32.3 \\
\hline Land \& Railway & 18 & 27.7 & 60.0 \\
\hline Supporting Industries & 26 & 40.0 & 100.0 \\
\hline \multicolumn{4}{|l|}{ Respondent Position } \\
\hline IT Managers & 22 & 33.8 & 33.8 \\
\hline Non-IT Managers & 43 & 66.2 & 100.0 \\
\hline \multicolumn{4}{|c|}{ Number of Years Official } \\
\hline \multicolumn{4}{|c|}{ Company Web Sites Developed } \\
\hline 1 & 5 & 7.7 & 7.7 \\
\hline 2 & 3 & 4.6 & 12.3 \\
\hline 3 & 11 & 16.9 & 29.2 \\
\hline 4 & 5 & 7.7 & 36.9 \\
\hline 5 & 8 & 12.3 & 49.2 \\
\hline 6 & 3 & 4.6 & 53.8 \\
\hline 7 & 5 & 7.7 & 61.5 \\
\hline 8 & 1 & 1.5 & 63.1 \\
\hline 9 & 2 & 3.1 & 66.2 \\
\hline 10 & 5 & 7.7 & 73.8 \\
\hline 11 & 8 & 12.3 & 86.2 \\
\hline 12 & 1 & 1.5 & 87.7 \\
\hline 13 & 4 & 6.2 & 93.8 \\
\hline 14 & 2 & 3.1 & 96.9 \\
\hline 15 & 1 & 1.5 & 98.5 \\
\hline 16 & 1 & 1.5 & 100 \\
\hline
\end{tabular}

Source: Developed for this study

For the industry sub-sector, a majority (40.00\%) of respondents supported industry companies, $27.69 \%$ were from land and railway companies, $26.15 \%$ were from sea freight companies, while the remaining $6.15 \%$ represented airfreight companies. Respondents' position showed that $66.15 \%$ of respondents were non-IT managers, and IT managers only represented $33.85 \%$. Further, it was found that most of the organizations had been operating 
the company web sites for three years $(16.9 \%)$.

\subsection{Reliability Test}

Reliability analysis was carried out to avoid any estimation bias and assess the consistency between multiple measurements of variables. Cronbach Alpha is the basic formula to determine data reliability based on internal consistency (Kim \& Cha, 2002). For this study, the minimum value of Cronbach Alpha is referred to a rule of thumb, which was suggested by Hair, Anderson, Tatham, and Black (2006). By this rule of thumb, 0.60 is the lowest Cronbach Alpha level, which considers data to be reliable. Results from this study's reliability test are shown in Table 4.2. It was found that the value of Alpha obtained for web functionalities is 0.949, which suggests that the scale is reliable for use in this study. Measures for regulatory support gave a value of 0.886 , which is also supportive. Reliability coefficients for managerial beliefs (0.823), firm scope (0.810), pressure intensity (0.668), and web technology investment (0.761) indicate high internal consistency among its statements. This is consistent with reports by Hair, Anderson, Tatham, and Black (2006). 
Table 4.2 Internal Consistency of the Construct

\section{CONSTRUCTS}

CRONBACH'S ALPHA

\section{Technology Competence}

TC1 (\% of employees use a computer at work)

TC2 (\% of employees have IT qualifications)

\section{Web Functionalities}

WF1 (Web sites support service review)

WF2 (Web sites support consumer customization)

WF3 Web sites support account management)

WF4 (Web sites support the registry of the online community)

WF5 (Web applications electronically integrated with the back-office system)

WF6 (Company databases electronically integrated with suppliers)

WF7 (Company databases electronically integrated with partners)

\section{Firm Scope}

FS1 ( $\%$ total sales from outside Malaysia)

FS2 (\% total procurement spending outside Malaysia)

FS3 (\% total business activities from outside Malaysia)

\section{Managerial Beliefs}

MB1 (Perceived increasing importance of web technology investment)

MB2 (Perceived that web technology increase market share)

MB3 (Perceived that web technology increase efficiency)

MB4 (Perceived that web technology improve knowledge sharing)

MB5 (Perceived that web technology improve communication)

MB6 (Perceived that web technology enhance customer service)

\section{Regulatory Support}

RS1 (Government demonstrates a strong commitment to promoting web 0.886 technology investment)

RS2 (Government provides high incentives for web technology investment)

RS3 (Business laws support web technology investment)

RS4 (There are legal protections for web technology usage)

\section{Pressure Intensity}

PI1 (Customer pressure)

PI2 (Supplier pressure)

PI3 (Competitors)

PI4 (Required by the government)

\section{Web Technology Investment}

CI (Firm's information system budget based on \% total revenue)

C2 (Firm's web-based spending based on $\%$ total revenue)

C3 (Describe the current web sites development)

Source: Computed data analysis 


\section{Discussion of Findings}

By looking at drivers for web technology investment, as reflected in Table 4.3, ones that have strongly significant influence towards web technology investment are web functionalities $(\beta$ $=0.463)$, followed by regulatory support $(\beta=0.243)$, firm size $(\beta=0.196)$, managerial belief $(\beta=-2.55)$, and pressure intensity $(\beta=-2.14)$. Hypothesis 2 regarding web functionalities had suggested various functionalities from a static presentation of content to active capture of transactions, as Chatterjee et al. (2002) mentioned. According to Zhu and Kraemer (2005), back-end integration allows for technology incorporation within organizations, allowing for smooth information sharing to be streamlined between suppliers and business partners.

Systinet (2002) has carried out a survey which found that firms that can provide more web functionalities are better prepared to assume web technology. Competent web functionalities will make customers as well as trading partners more agreeable to perform online transactions. In support of hypothesis 3 , results from this study were similar to previous researchers' findings who discovered that firm size had a positive relationship towards web technology investment (Mohamed et al., 2009; Oliveria et al., 2008). According to Mohamed et al. (2009), Oliveria and Martins (2008); also, Lippert and Govindarajulu (2006), there is a good relationship between firm size and IT adoption.

Hypothesis 5 was supported by Mohamed et al. (2009), who identified that senior management support could make web technology investment a success. This finding is also consistent with another study conducted by Chen et al. (2006), who found that the most significant factor in stimulating innovation is top administration leadership. Hypothesis 6 is accepted and shows that regulatory support has the most significant positive relationship with an organizational commitment to security controls implementation. Delmas (2002) recommended that if regulatory agencies necessitate adopting specialized standards, firms may experience higher transaction costs to meet the necessary objective. According to a study by Dasgupta et al. (1999), companies operating in restricted government policies would have a lower IT adoption rate. Pressure intensity is measured by looking at pressure exerted by customers, the pressure exerted by suppliers, the pressure exerted by competitors, and requirements enforced by regulatory bodies within the context of web technology investment. Hypothesis 7 was supported by the findings of Cristobal, Flavian, and Guinaliu (2007), who studied e-service and customer loyalty. It was further established that the growing level of competition, which can be observed on the Internet, would require an analysis of factors that can fully explain aspects that would largely determine consumer loyalty. Company web sites should be user-friendly to ease consumer purchasing and searching, thus creating a suitable framework for higher satisfaction and loyalty levels. Table 4.3 shows a summary of the hypotheses tested in this study: 
Table 4.3 Summary of Results - Hypotheses Testing

\begin{tabular}{lllll}
\hline & Hypothesis & & Findings \\
H1 & $\begin{array}{l}\text { Technology competence significantly influences web } \\
\text { technology investment }\end{array}$ & Reject \\
\hline H2 & $\begin{array}{l}\text { Web functionalities significantly influence web technology } \\
\text { investment }\end{array}$ & Do not reject \\
\hline H3 & $\begin{array}{l}\text { Firm size significantly influences web technology } \\
\text { investment }\end{array}$ & Do not reject \\
\hline H4 & $\begin{array}{l}\text { Firm scope significantly influences web technology } \\
\text { investment }\end{array}$ & Reject \\
\hline H5 & $\begin{array}{l}\text { Managerial beliefs significantly influence web technology } \\
\text { investment. }\end{array}$ & Do not reject \\
\hline H6 & $\begin{array}{l}\text { Regulatory support significantly influences web technology } \\
\text { investment. }\end{array}$ & Do not reject \\
\hline H7 & $\begin{array}{l}\text { Pressure intensity significantly influences web technology } \\
\text { investment. }\end{array}$ & Do not reject \\
\hline
\end{tabular}

Source: Computed data analysis

\section{Conclusion}

This study has achieved all the objectives that it was intended to fulfill. This study is expected to expand the body of knowledge in web sites or IT areas, especially within the Malaysian logistics sector, by providing evidence on factors determining web technology investment. Based on findings from this study, web functionalities, firm sizes, managerial beliefs, regulatory support, and pressure intensity were found to have a significant positive influence on web technology investment.

However, due to several limitations, this study's results cannot be merely generalized to all registered companies in the Malaysian logistics industry. To some extent, the result of this study can be used as a guideline for regulatory bodies. Other recommendations derived from this research's findings are that the top management typically decides to adopt new technology. Hence, these logistics companies' top management need to develop strategies to support their companies in fully capitalizing on opportunities presented by their web sites and related IT tools.

In moving forward, researchers can diversify the TOE model's application to various industries, especially with the rise of the gig economy recently. With further business models being put forward, it becomes necessary to examine whether online-based businesses can sustain in the long run. The current study would also suggest looking into different aspects of business operation, which also embeds technology in their daily process. This ensures that technology is indeed bringing benefit in simplifying an organization's process, rather than bringing more hassle to the management in ensuring the smooth running of the business. 


\section{Acknowledgment}

We would like to thank the Accounting Research Institute, Universiti Teknologi MARA Malaysia, and Ministry of Higher Education Malaysia for the research fund (600-RMC/ARI 5/3(026/2020)) for publishing this article.

\section{References}

Ahmed, F., Qin, Y. J., \& Martínez, L. (2019) Sustainable change management through employee readiness: Decision support system adoption in technology-intensive British e-businesses. Sustainability, 11(11), 2998. https://doi.org/10.3390/su11112998

Ainscough, T., \& Luckett, M. (1996). The Internet for the rest of us: Marketing on the World Wide Web. Journal of Consumer Marketing, 13(2), 36-47. https://doi.org/10.1108/07363769610115393

Ajzen, I. (1985). From Intentions to Actions: A Theory of Planned Behavior. In: Kuhl, J., Beckmann, J. (eds.) Springer Series in Social Psychology. Berlin: Springer. https://doi.org/10.1007/978-3-642-69746-3_2

Al-Qirim, N. (2007). A research trilogy into e-commerce adoption in small businesses in New Zealand. Electronic Markets, 17(4), 263-285. https://doi.org/10.1080/10196780701635872

Bellaaj, M., Bernard, P., Pecquet, P., \& Plaisent, M. (2008). Organizational, environmental, and technological factors relating to benefits of website adoption. International Journal of Global Business, 1(1), 44-64.

Benbunsn-Fich, R., \& Fich, E. (2005). Measuring the value of redesigning a web presence. Journal of Electronic Commerce in Organizations, 3(1), 35-52. https://doi.org/10.4018/jeco.2005010103

Burke, L. A., \& Witt, L. A. (2002). Moderators of the openness to experience performance relationship. Journal of Managerial Psychology, 17, 712-721. https://doi.org/10.1108/02683940210450501

Carmeli, A., Dothan, A., \& Boojihawon, D. K. (2019). Resilience of sustainability-oriented and financially-driven organizations. Business Strategy and the Environment, 29(1), 154-169. https://doi.org/10.1002/bse.2355

Castleman, T., Swatman, P. A., \& Swatman, P. M. C. (2000). The role of government in internet commerce: Views from the fields, 13th Bled International Electronic Commerce Conference, Bled, Slovenia, 265-284.

Charchill, G. A., \& Brown, T. J. (2004). Basic Marketing Research, Thomson Corporation, USA.

Chatterjee, D. D., Pacini, C., \& Sambamurthy, V. (2002). The shareholder-wealth and trading-volume effects of information-technology infrastructure investments. Journal of 
https://doi.org/10.1080/07421222.2002.11045723

Chen, A. N. K. S., Sen, B., \& Shao, B. M. (2006). Strategies for effective web services adoption for dynamic e-businesses, Decision Support Systems, 42, 789 -809. https://doi.org/10.1016/j.dss.2005.05.011

Cristobal, E., Flavian, C., \& Guinaliu, M. (2007). Perceived e-service quality measurement validation and effects on consumer satisfaction and web site loyalty. Managing Service Quality, 17(3), 317. https://doi.org/10.1108/09604520710744326

Coltman T., Devinney, T. M., \& Midgley, D. F. (2003). Strategic drivers and organizational impediments to ebusiness performance: An empirical evaluation. Aism-INSEAD Conference on Expanding Perspective on the Strategy Processes, August, 24-26. https://doi.org/10.2139/ssrn.392562

Cremer, R. D., \& Ramasamy, B. (2009). Engaging China: Strategies for the small internationalizing firm. Journal of Business Strategy, 30(6), 15-26. https://doi.org/10.1108/02756660911003086

Dasgupta, S., Agarwal, D., Ioannidis, A., \& Gopalakrishnan, S. (1999). Determinants of information technology adoption: An extension of existing models to firms in a developing country. Journal of Global Information Management, 7(3), 41-49. https://doi.org/10.4018/jgim.1999070103

Davis, F. (1989). Perceived usefulness, perceived ease of use, and user acceptance of information technology. MIS Quarterly, 13(3), 319-340. https://doi.org/10.2307/249008

Delmas, M. A. (2002). The diffusion of environmental management standards in europe and in the United States: An institutional perspective. Policy Sciences, 35(1), 91-119. https://doi.org/10.1023/A:1016108804453

Dewan, S., Michael, S., \& Min, C. (1998). Firm characteristics and investments in information technology: Scale and scope effects. Information Systems Research, 9(3), 219232. https://doi.org/10.1287/isre.9.3.219

Fishbein, M., \& Ajzen, I. (1977). Belief, Attitude, Intention and Behavior: An Introduction To Theory and Research. Reading: Addison-Wesley.

Georgise, F. B., Heramo, A. H., \& Bekele, H. (2020). Improving automotive service through e-logistics: A case of Moenco Hawassa, Ethiopia. International Journal of Economics and Management Systems, 5, 21-40.

Goh, H. P. (1996). The Diffusion of Internet in Singapore: A Content Analytic Approach. Faculty of Business Administration, National University of Singapore.

Hasan, L., \& Abuelrub, E. (2006). Criteria for evaluating quality of web sites. Proceedings of the 6th IBMA International Conference on Managing Information in Digital Economy, 
Germany.

Hasan, H., \& Gould, E. (2001). Support for the sense-making activity of managers. Decision Support Systems, 31(1), 71-86. https://doi.org/10.1016/S0167-9236(00)00120-2

Hair, J. F., Jr., Black, W. C., Babin, B. J., Anderson, R. E., \& Tatham, R. L. (2006). Multivariate Data Analysis (Sixth Edition). Upper Saddle River: Pearson Prentice Hall.

Hitt, L. (1999). Information technology and firm boundaries: Evidence from panel data. Information Systems Research, 10(2), 134-149. https://doi.org/10.1287/isre.10.2.134

Hussey, J., \& Hussey, R. (1997). Business research: A practical guide for undergraduate and postgraduate student. Great Britain: Macmillan Press Ltd. https://doi.org/10.1007/978-1-349-25262-6

Igbaria, M., Zinatelli, N., \& Cavaye, A. (1998). Analysis of information technology success in small firms in New Zealand. International Journal of Information Management, 18, 103-119. https://doi.org/10.1016/S0268-4012(97)00053-4

Kalakota, R., \& Whinston, A. B. (1996). Readings in Electronic Commerce. Addison Wesley Publishing, Reading, MA.

Kim, W. G., \& Cha, Y. (2002). Antecedents and consequences of relationship quality in hotel industry. Hospitality Management, $321-338$. https://doi.org/10.1016/S0278-4319(02)00011-7

Lin, C. Y., \& Ho, Y. H. (2008). An empirical study on logistics service providers intention to adopt green innovations. Journal of Technology Management \& Innovation, 3, 17-26.

Lippert, S. K., \& Govindarajulu, C. (2006). Technological, organizational, and environmental antecedents to web services adoption. Communications of the IIMA, 6(1), 146-158.

MacKay, N., Parent, M., \& Gemino, A. (2004). A model of electronic commerce adoption by small voluntary organizations. European Journal of Information Systems, 13(2), 147-159. https://doi.org/10.1057/palgrave.ejis.3000491

Martins, R., Oliveira, T., Thomas, M., \& Tomás, S. (2019), Firms' continuance intention on SaaS use - an empirical study, Information Technology \& People, 32(1), 189-216. https://doi.org/10.1108/ITP-01-2018-0027

Ministry of International Trade and Industry Malaysia. (2010). Retrieved from Http://Portal.Miti.Gov.My/Storage/Documents/B8b/Com.Tms.Cms.Document.Document_Af ff64f5-C0a81573-2dc72dc76a3d49e9/1/Miti_Laporan_Tahunan_2010_Malay.Pdf March 30, 2010)

Mohamed, I. S., Omar, N., \& Daud, M. N. (2009). Assessing drivers of web technology investment in malaysia service industry: An application of technological, organizational, and environmental (TOE) model. International Conference on Information and Multimedia 
Technology, 221-225. https://doi.org/10.1109/ICIMT.2009.73

Nguyen, H. P. (2020). Human resource management of logistics in Vietnam: Status and policy solutions. International Journal of Innovation, Creativity and Change, 11(3), 569-583.

Oliveira, T., \& Martins, M. F. O. (2008). A comparison of web site adoption in small and large Portuguese firms. Ice-B 2008: Proceedings of the International Conference on E-Business, Porto, Portugal, July, 370-377.

Oliveira, T., \& Martins, M, F. O. (2011). Literature review of information technology adoption models at firm level. The Electronic Journal Information Systems Evaluation, 14(1), 110-121.

Porter, M. E. (1995). The competitive advantage of the inner city. Harvard Business Review, $73(3)$.

Reich, B. H., \& Benbasat. (1990). An empirical investigation of the factors influencing the success of customer-oriented strategies systems. Information Systems Research, 325-347. https://doi.org/10.1287/isre.1.3.325

Rogers, E. (1995). Diffusion of Innovations (4th ed.). New York.

Salahshour Rad, M., Nilashi, M., \& Mohamed Dahlan, H. (2018). Information technology adoption: a review of the literature and classification. Universal Access in the Information Society, 17, 361-390. https://doi.org/10.1007/s10209-017-0534-z

Sekaran, U. (2003). Research Methods for Business. New York, NY: John Wiley and Sons, Inc.

Schniederjans, M. J., Hamaker, J. L., \& Schniederjans, A. M. (2004). Information Technology Investment: Decision-Making Methodology. New Jersey: World Scientific Publishing Company River Edge. https://doi.org/10.1142/5424

Swanson, E. B. (1994). Information systems innovation among organizations. Management Science, 40(9), 1069-1090. https://doi.org/10.1287/mnsc.40.9.1069

Systinet. (2002). Survey Shows Sharp Increase in Adoption of Web Services in 2003. Retrieved from http://Www.Systinet.Com/News/Latest_News/Article\&Id_Ele=27

Tan, K. S., Chong, S. C., \& Lin, B. (2010). Internet-based ICT adoption among SMEs: Demographics versus benefits, barriers, and adoption intention. Journal of Enterprise Information Management, 23(1), 27-55. https://doi.org/10.1108/17410391011008897

Tarofder, A. K., Marthandan, G., \& Haque, A. (2010). Critical factors diffusion of web technologies for supply chain management functions: Malaysian perspective. European Journal of Social Sciences, 12(3), 490-505.

Terence, T. S. E. (2007). Reconsider the source of value and e-business strategies. Journal of John Wiley \& Sons Ltd. 
Thurasamy, R., Mohamad, O., Omar, A., \& Marimuthu, M. (2009). Technology adoption among small and medium enterprises (SME's): A research agenda. World Academy of Science, Engineering and Technology, 53, 943-947.

Toh, M. H., \& Low, L. (1993). The intelligent city: Singapore achieving the next lap. Technology Analysis and Strategic Management, 5(2), 187-202. https://doi.org/10.1080/09537329308524129

Tornatzky, L. G., \& Fleischer, M. (1990). The Processes of Technological Innovation. Lexington, MA: Lexington Books.

Turban, E., \& King, D. (2006). Introduction to E-commerce. Prentice Hall.

Venkatesh, V., Morris, M., Davis, G., \& Davis, F. (2003) User acceptance of information technology: toward a unified view. MIS Quarterly, 27(3), 425-478. https://doi.org/10.2307/30036540

Weill, P., \& Olson, M. H. (1989). Managing investment in information technology: Mini case examples and implications. MIS Quarterly, 13(1), 3-17. https://doi.org/10.2307/248694

Zhu, K., \& Kraemer, K. L. (2005). Post-adoption variations in usage and value of e-business by organizations: Cross-country evidence from the retail industry. Information Systems Research, 16(1), 61-84. https://doi.org/10.1287/isre.1050.0045

Zhu, K., Kraemer, K. L., \& Xu, S. (2006). The process of innovation assimilation by firms in different countries: A technology diffusion perspective on e-business. Management Science, 52(10), 1557-1576. https://doi.org/10.1287/mnsc.1050.0487

\section{Copyright}

Copyright for this article is retained by the author(s), with first publication rights granted to the journal.

This is an open-access article distributed under the terms and conditions of the Creative Commons Attribution license (http://creativecommons.org/licenses/by/4.0/). 